\title{
Application of Storytelling Method in Early Childhood Education Institute as the Implementation of Permendikbud No. 146 of 2014 in Appendix IV in the Manual Learning of Early Childhood Education
}

\author{
Malpaleni Satriana \\ Early Childhood \\ Universitas Mulawarman \\ Samarinda, Indonesia \\ malpa.mz@gmail.com
}

\author{
Farny Sutriany Jafar \\ Early Childhood \\ Universitas Mulawarman \\ Samarinda, Indonesia \\ farny_sutriany
}

\author{
Wiwik Haryani \\ Early Childhood \\ Universitas Mulawarman \\ Samarinda, Indonesia \\ malpa.mz@gmail.com
}

\begin{abstract}
The objective of this research is to find out how storytelling implemented by the teachers in ECE centers based on the Act No. 146 of 2014 on the attachment of IV about the guidance of ECE practices. This research used a qualitative approach. 10 (ten) teachers at ECE centers of Muara Badak District, East Kalimantan was involved in this research. The result of this research revealed that the role of the teachers is very important in their practice how to teach to the children by storytelling. This storytelling method used media of learning and without media in their practices. The teacher should have the abilities to make media of learning which is its use to teach to the children. Besides that, the teacher should practice its media based on the learning strategy in ECE.
\end{abstract}

Keywords - learning methods, storytelling without tools, storytelling with display tools

\section{INTRODUCTION}

The task of early childhood development should be tangible in the mindset, behavior, and actions. Developmental tasks in each age range have unique and distinctive features in how to learn them. In fact, the embodiment of the indicator in every developmental task of a child is naturally evolved, known as the maturity process and some of the development through stimulation conditioned by parents, teachers or other adults around the child such as the ability to imitate the behavior of an adult whom child sees.

The task of early childhood development should be tangible in the mindset, behavior, and actions. Developmental tasks in each age range have unique and distinctive features in how to learn them. In fact, the embodiment of the indicator in every developmental task of a child is naturally developed, known as the maturity process and some that develop through stimulation conditioned by parents, teachers or other adults around the child.

One of the media offered in this study is the storytelling method for early childhood, in accordance with Permendikbud No.146 on the Curriculum of ECD, in Appendix IV on the Guideline for Learning. This storytelling method consists of a method of telling stories with props and storytelling methods without props. In this activity, at the beginning of the teachers will get a comprehensive understanding of what, why and how to tell the story method for early childhood. Followed by the practice of storytelling in early childhood institutions who attended the training.

The issues to be discussed are formulated and constrained so that the discussion is directed to the intended target in the form of research questions (1) how is the theoretical concept of storytelling method for early childhood? (2) how to practice the storytelling method with props in early childhood? How to practice the storytelling method without props in early childhood?

After this study is done, it is expected to obtain the benefits that can open the insight and provide new methods in the application of storytelling methods in early childhood institutions, as the implementation of Permendikbud No.146 of 2014 attachment IV on the guidance of learning early childhood, they are below.

\section{1) Parents and Teachers of Early Childhood}

It is expected that the knowledge of teachers and parents about how should the process of early childhood learning activities, especially about the method of telling stories with props and without props in early childhood.

\section{2) For Early Childhood Institutions}

Through this activity, early childhood education will be able to provide the best service for students in accordance with the stages of development, through the method of telling stories with props and without props in early childhood professionally.

\section{3) Academics}

This activity is the implementation of tri dharma mutualism college, where the results obtained as feedback from the field can again be input for further development.

Storytelling is an activity that someone does orally to others with props or tools about what should be conveyed in the form of messages, information or just a fairy tale to be heard with a sense of fun, because the person who presents the story presents it interestingly [1]. According to Big Indonesian Dictionary [4], the story is a speech that unfolds how the occurrence of a thing or event or essay that tells the deed, experience of happiness or suffering of people, the incident is real or fictitious. 
In line with that, Musfiroh [3] also states that the story is an oral speech, a work of writing or staging about an event, events, and so on that occur around the world of children. While Depdiknas [2] defines that the method of storytelling is a way of speaking in the delivery of stories or provide explanations to children orally, in an effort to introduce or provide information on new things in children.

Storytelling with props, which in practice uses visual aids as an explanatory medium of a story that child is listening to, so the child's imagination of a story does not deviate much from what the teacher means. The props used can be: (1) Direct aids, e.g using original objects or actual objects, so that children can understand the contents of the story and can see directly the characteristics and usefulness of the tool; (2) Indirect props can be, that is, using objects that are not actual tools. Storytelling with indirect props in the form of a) Storytelling with artificial objects. b) Storytelling by using pictures. c) Storytelling using the flannel board. d) Read the stories. e) The puppet play.

\section{LITERATURE}

\section{A. Storytelling}

The storytelling activities provide a great deal of learning value for the learning and developmental process of the child and can foster an interest and a passion for reading, Jensen [11] "to read stories aloud to children can substantially contribute to children's story knowledge and awareness of reading ". M Solehuddin [11] "in addition to creating a fun atmosphere, telling stories can invite and stimulate the process of cognition, especially imagination activities. It can develop a basic readiness for language development and literacy, can be a means to learn, and can work to build a close relationship. Stories for children should be appropriate to the child's developmental stage. Tampubolon [4] "the content of the story should correspond to the level of the child's thoughts and experiences".

Storytelling in accordance with the development of children in the concept of Development Appropriate Practice (DAP) from The National Association for the Education of Young Children (NAEYC), which is storytelling in accordance with the guidelines of children's education [4], the story contains some of the requirements that educators need to meet:

1) Understand the notions and problems surrounding stories and tell stories. In this concept, educators need to make sure what the story tells, what is the difference between storytelling, and how the concept of presentation tells stories that support the development of children in various aspects.

2) Understand the basic assumption of child development assumptions. Educators need to be aware that children develop according to specific phases. Children aged 4-7 years are in the preoperative phase with different developmental characteristics in children over that age.

3) Understand the meaning and task of child development.In kindergarten, children need to introduce good and bad concepts through examples to help them achieve the moral development task of that age.

4) Understand the developed domain and development theory. Teachers need to know about developmental theory and believe it in the practice of storytelling (especially) and learning (generally), not blind directions. Each developmental theory has characteristics that distinguish it from other theories.

5) Understand the concept of learning and teaching.

The narrator needs to understand that the child learns not through lectures, but through the active and active interaction of children with learning materials. Through stories, children engage themselves actively, gladly and intrinsically motivated to build "good-bad", "right-wrong", "exact-no" concepts presented in the story.

6) Understand the concept of "developmental progress" in the instructional practice guidelines or Development Appropriate Practice (DAP). Educators need to be aware that stories should be tailored to the child's developmental level, including abilities of children in language, thinking, social, emotional, motor and moral, without understanding this story will be too difficult (so incomprehensible to children) or too easy (boring for children).

In the implementation of storytelling methods can be divided into two kinds, namely storytelling without props and storytelling with props. Storytelling without props Where in the implementation without using props as a medium of storytelling and teachers should pay attention to facial expressions, gestures, and the voice of teachers should be able to help the child's fantasies to fantasize things that are told by the teacher. Storytelling with props where in the implementation using visual aids as an explanatory media of stories that children listen to, so the child's imagination of a story is not too deviate from what is intended by the teacher.

The props used can be (1). direct props, e.g using real objects or actual objects (e.g rabbits, flowers, plates) so that children can understand the contents of the story and can see directly the characteristics and usefulness of the tool. (2) indirect props can be using objects that are not actual tools. Storytelling with indirect props can be: storytelling with artificial objects; storytelling using pictures; storytelling using flannel boards; read stories; puppet show.

\section{B. Early Childhood Learning Strategies}

David, quoted in Gulo [5], states that teaching and learning strategies are a plan, method, or series of activities designed to achieve a particular educational goal. Based on this understanding, the learning strategy can be defined as planning which contains about a series of activities designed to achieve certain educational goals that include plans, methods, and tools of activity.

In the application and choose a learning strategy, there are several components that must be considered for learning activities can achieve a predetermined goal. In this regard, Sanjaya [6] states that learning process consists of components that interact and interrelate. Some of these components are objectives, learning materials, methods, media, and evaluation.

Sujiono and Sujiono [7] stated that the selection of learning strategies should be determined based on the criteria: (1) the orientation of the strategy on the task of learning, (2) relevant to the content/learning materials, (3) the methods and techniques used are focused on the 
intended purpose achieved, and (4) learning media used to stimulate the senses learners simultaneously. In accordance with these criteria, it can be seen that in choosing a learning strategy should pay attention to the task of learning, learning materials, methods and techniques, and the media have given to the students as a tool of learning. Therefore, the selection of effective learning strategies is a skill that must be owned by an educator or teacher. The selection of appropriate and appropriate strategies will determine the success of learning objectives.

\section{METHOD}

The objectives in this study are as follows (1) knowing the theoretical concepts of storytelling methods for early childhood, (2) knowing how to practice storytelling methods with props in early childhood, (3) know how to practice storytelling method without props in early childhood.

The method used in this study is a case study that provides these training activities are lectures, questions, and answers, demonstrations and practice directly at each ECD. Submission of materials and practices is done with a persuasive educative approach that emphasizes more on the development aspect and potential mobilization of the participants. In accordance with the approach and method used in this training, the activities are done in detail by:

- Cooperation with various organizations of early childhood educator profession, to get data about teachers in the sub-district of Muara Badak.

- Conducting socialization about community service activities that will be implemented.

- Conducting meetings to start activities in accordance with the design of activities beginning with the delivery of the material as a whole in the form of theoretical and practical knowledge

- Demonstration of the method of telling stories in early childhood

- The direct practice of telling stories with props

- The direct practice of storytelling without props

- Conducting evaluation of activities

- Prepare a report of community service

Research Activities Implementation of Storytelling Method In Early childhood Institution as Implementation of Permendikbud No.146 Appendix IV About Early Childhood Learning Guidance [8], conducted in ten early childhood institutions located in Sub-district of Muara Badak - East Kalimantan, 2017.

\section{RESUlt AND DisCUSSION}

Evaluation is done after the trial process takes place, with the success criteria:

- Teachers can do storytelling preparation process with props and without props

- Teachers can do the story-telling process using props and without props.
- Teachers and children can do participatory stories together using props and without props.

- Children can retell the story using props and without props.

Material development is done by considering the practicality, meaning that because the target of this activity is the participants can understand the importance of using the storytelling method in the process of learning activities with the students. So that in its use as a medium messenger will be accepting of children with fun. After deep discussion, the material presented consists of:

- Development of the story by using storytelling method with props.

- Developing stories using storytelling methods without props

- Implementation of media on teaching

Implementation of this study has been in accordance with the previous goal, namely to provide an understanding of knowledge and practice directly. Teachers can make some alternative learning methods in early childhood institutions as attached to IV Learning Guidance in Permendikbud 146 [8]. The storytelling method is used for messengers in early childhood. This needs to get the attention of the teachers, because, through the storytelling method and character story characters, children can better understand what messages teachers want to convey, in participants with teachers and children. This activity also proved to be a solution to the method of learning in early childhood, so it can not be adapted to the theme of different stories. Through the creativity of teachers doing a participatory story with children using the method of telling stories using tinsel and without props, it is expected the learning messages from teachers will be conveyed with fun for young children.

\section{CONCLUSION}

Research Program Application of Storytelling Method In early childhood Institution as Implementation of Permendikbud No.146 of 2016 Appendix IV about Early Childhood Learning Guideline, has been implemented through 3 stages. The stage is the first stage of socialization research design. The second phase of seminars and training of storytelling using props and without props. The third stage is a test of the implementation of the storytelling method using visual aids and without props for early childhood in early childhood institutions.

Research programs that have been implemented, managed to achieve the targets that have been determined, where each storytelling method can be used by teachers with communicative with children. Teachers become more creative in issuing ideas to produce story themes and storytelling media as a supporter of the story message delivered. Children also seem more enthusiastic to follow the story and more quickly find out the message from the story. Children are able to participate so that the children's understanding of the story presented by the previous teacher has shown. 


\section{REFERENCES}

[1] Catron, C.E. \& Allen, J, Early Childhood Curriculum A Creative-Play Model. New Jersey: Merill, Prentice-Hall, 1999.

[2] Depdiknas, Apa, Mengapa, dan Siapa yang Bertanggungjawab Terhadap Anak Usia Dini. Jakarta: Depdiknas, 2004.

[3] Musfiroh T, Cerita Untuk Perkembangan Anak. Yogyakarta: Navila, 2005.

[4] Abdurrahman, Mulyono, Pendidikan Bagi Anak Berkesulitan Belajar. Jakarta: Rineka Cipta, 2003.
[5] Gulo, W, Strategi Belajar Mengajar. Jakarta: Grasindo, 2002

[6] Sujiono, Yuliani, Nurani, Konsep Dasar Pendidikan Anak Usia Dini. Jakarta: Indeks, 2009.

[7] Sujiono, Yuliani, Nurani and Bambang, Sujiono, Bermain Kreatif Berbasis Kecerdasan Anak. Jakarta: Indeks, 2010.

[8] Depdiknas, Permendikbud 146 tentang Pendidikan Usia Dini. Jakarta: Depdiknas, 2014. 